\title{
Exploring the Impact of and Perceptions about Interactive, Self-Explaining Environments in Molecular- Level Animations
}

David A. Falvo ${ }^{\star 1}$, Michael J. Urban ${ }^{2}$ And Jerry P. Suits 3

$\approx$ This mixed-method study investigates the effects of interactivity in animations of a molecular-level process and explores perceptions about the animated learning tool used. Treatments were based on principles of cognitive psychology designed to study the main effects of treatment and spatial ability and their interaction. Results with students $(n=189)$ showed that science majors scored higher than non-science majors in retention measures (i.e., structure and function) but not in transfer. Significant main effects were found for treatment in function questions and spatial ability in structure questions. There was a significant interaction between treatment and spatial ability in structure questions. Additionally, in this study participants believed the key and the motion of ions and molecules were the most helpful parts of the animation. This study shows that students perceive the animations as being supportive of their learning, suggesting that animations do have a role in science classrooms.

Keywords: Interactive learning environments, Simulations, Visualisations

$1 \quad{ }^{\star}$ Corresponding author. Richard W. Riley College of Education and Leadership Walden University, 155 Fifth Ave. South, Suite 100, Minneapolis, MN 55401 david.falvo@waldenu.edu

2 Professional Education, Campus Box 35, Bemidji State University, Bemidji, MN 56601

3 Chemistry \& Biochemistry, Campus Box 98,University of Northern Colorado, Greeley, CO 80639 


\section{Študija vpliva in zaznavanja interaktivnih samorazlagalnih okolij animacij molekularne ravni}

David A. Falvo*, Michael J. Urban in Jerry P. Suits

$\propto$ Študija, izvedena po kombiniranem raziskovalnem pristopu, je ugotavljala učinke interaktivnosti $\mathrm{v}$ animacijah procesa na molekularni ravni in zaznave, povezane s tem animacijskim učnim orodjem. Obravnava učne vsebine je temeljila na načelih kognitivne psihologije, proučevani pa so bili glavni učinki obravnave vsebine in prostorske sposobnosti udeležencev. Rezultati učnega uspeha študentov $(n=189)$ kažejo, da študentje naravoslovja dosegajo višje rezultate kot študentje nenaravoslovnih ved pri preverjanju pomnjenja vsebine (npr. struktura in funkcija), ne pa tudi pri transferu znanja. Pomembni učinki so bili ugotovljeni pri obravnavi vsebine, kadar so bila vprašanja povezana s funkcijo in prostorskimi sposobnostmi, ne pa tudi pri vprašanjih, povezanih $s$ strukturo. Pomembna povezava pa je med obravnavo vsebine in prostorskimi sposobnostmi, kadar so bila vprašanja povezana s strukturo. Udeleženci raziskave so izrazili, da sta bila legenda ter gibanje ionov in molekul del animacije, ki jim je bil najbolj v pomoč pri učenju. Študija ugotavlja, da študentje dojemajo animacije kot učinkovito podporo pri učenju, zato imajo pomembno vlogo pri pouku naravoslovja.

Ključne besede: vizualizacija, interaktivna učna okolja, simulacije 


\section{Introduction}

A great deal of research has been conducted about improving students' conceptual understandings of chemistry at three different representation levels (i.e., symbolic, particle and macroscopic levels) (Johnstone, 1993; Gabel, 2005). Nurrenbern and Pickering (1987), Sawrey (1990), and Nakhleh (1993) claim that traditional instruction tends to focus on the symbolic level (see Figure 1) in lectures and the macroscopic level in the laboratory. Research has led to specific design principles for instructional multimedia (Chandler \& Sweller, 1991; Mayer, 2001). Words and pictures should be used simultaneously and should be presented close to each other in space, while narration should be provided in audio format. Additionally, visualisations and symbols augment human cognitive capacities and help to convey concepts and information (Tversky, 2001).

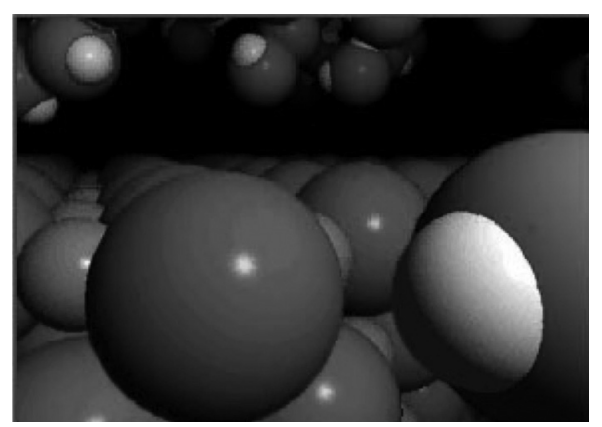

Figure 1: Image of molecules from salt dissolving in water animation.

Historically, there have been problems in the use of animations for teaching. Due to the fact that animations sometimes mislead learners, causing misunderstandings, there has been a history of caution about using these tools for teaching. Viewers often interpret movements of forms and figures in an animation as having causality, relationships and even intentions (Martin \& Tversky, 2003; Tasker, 2004; Tversky, 2005). Learners assume that the colours and the shapes reflect the actual reality of the represented items, whereas the shapes and colours are, in fact, either symbolic or an idealisation of time and space relations. When effectively designed and used, these visualisations help to ensure adequate perception and comprehension in the real-world context of student learning (Kelly, 2005; Tasker, 2004; Tversky, 2001; Zacks \& Tversky, 2003). 


\section{Theoretical Framework}

Several studies of self-explaining environments show the effectiveness of this technique (Chi, 1996, 2000). Two studies have shown that students enhance their mental models when they engage in defining explanations of concepts and processes (Chi, 2000; Chi, DeLeeuw, Chiu, \& Lavancher, 1994). In another study, researchers found that having students explain a concept using prior knowledge and cognitive reasoning improved the transfer of knowledge learning about the process (Atkinson, Renkl, \& Merrill, 2003). Transfer of knowledge learning is defined as the ability to apply knowledge or skills learned in one context to another context.

In addition, several learner characteristics can affect how learners perceive and interact with animation features, and may alter the cognitive load they experience (Cook, 2006). In order to study the spatial ability effect on learning from an animation (Schar \& Zimmermann, 2007), students were classified as "high spatial" or "low spatial" (Peters et al., 1995; Vandenberg \& Kuse, 1978). High-spatial learners may learn better when visual and verbal information is presented simultaneously rather than successively. Conversely, lowspatial learners may not benefit from this design feature (Mayer \& Moreno, 2003). Prior knowledge, a covariate in the present study, can influence the representations processed in working memory and how these representations are organised into coherent mental models (Cook, 2006; Schnotz, 2002). There is a difference between how novices and experts process information from an unfamiliar visual representation. Novices focus on the surface features of their perceptual representation, while experts link this representation to a higher level that involves conceptual understanding of the material. Experts omit irrelevant perceptual information and abstract required information from their relevant prior knowledge. Their long-term memory is organised and retrieved as well-developed schemas (Chi, Glaser, \& Rees, 1982). Conversely, novices can be confused by visualisations because they lack the prior knowledge to distinguish between relevant and irrelevant information (Linn, 2003).

\section{Research Focus}

This study investigated the interactive environments in a molecular animation in a classroom setting rather than in a laboratory (Cook, 2006). The animation featured sodium chloride (salt) dissolving in water at the molecular level (Tasker et al., 2002). Students saw structures of solid sodium chloride, water molecules, and the structures that resulted when water molecules dissolved 
the ionic structures of sodium chloride crystals. They witnessed the function of the sodium-chloride ionic attraction that resisted this dissolving process and the opposing function where the water-ion attraction overcomes this resistance to dissolve these ions.

The research questions for this study were:

- $\quad$ RQ1) Does treatment (i.e., type of interactivity and the self-explaining environment used in the molecular-level animation) affect performance on the dependent variables, which are the post-test knowledge assessments?

- $\quad$ RQ2) Does spatial ability (high or low) affect performance on the dependent variables, which are the post-test knowledge assessments?

- $\quad$ RQ3) Is there a significant interaction between spatial ability and the treatment (version of the animation) that students engaged with during the study?

\section{Method}

\section{Participants}

First-year students $(n=189)$ at a Midwestern university participated in the study. These university students were either first-year science majors or elementary education majors. The volunteers were randomly assigned to one of the treatment groups or to the control group. Participants in the qualitative component of the study came from the same pool of individuals. Five females ranging between the ages of 18 and 25 volunteered to take part in the phenomenology with semi-structured interviews (Creswell, 1998).

\section{Instruments}

Students completed a demographic survey about their prior experience in science, as well as providing information about their age, gender and characteristics. Their spatial ability was assessed using the Vandenberg spatial ability assessment (Peters et al.,1995; Vandenberg \& Kuse, 1978). Students also took a post-test, which was a knowledge assessment about the topic presented in the animation (i.e., salt dissolution in water at the molecular level). This test included structure and function questions that were used as retention measures. 


\section{Research design}

Prior to watching the animation of sodium chloride (salt) dissolving in water (Tasker et al., 2002), students viewed the components of the animation (e.g., see Figure 2), which were detailed on a table within the interface. The first version of the animation was basic, including just the visuals and narration, and students were able to replay the animation. In the second version, students had the option of pausing the animation at any time and were able to replay the animation if they so desired. In the third version, the animation automatically paused at selected points (i.e., segments) in order to create five short sections. At each pause point the viewer/student was prompted to either replay the previous section or to move on to the next section. The viewers also had the ability to, at any time, view any of the five sections in any order. The final version of the animation paused between each of the five sections and students were prompted to self-explain what they were seeing and thinking. They did this in a textual format. Students were allowed to revisit each section of the animation in any order.

\section{Treatment: Four versions of an interactive/self-explaining environment}

The animations used in this study illustrated the process of sodium chloride (salt) dissolving in water at the molecular level (Tasker et al., 2002). It was modified with Flash to create four different versions based on cognitive principles of instructional design. Students viewed the components of the animation (e.g., see Figure 2) before interacting with one of its four versions.

\section{Version 1 - Control (Animation Only)}

The animation played through from start to finish. Students were able to replay the animation if they so desired.

\section{Version 2 - Pause Button.}

Students had the option of pausing the animation at any time. Students were able to replay the animation if they so desired.

\section{Version 3 - Pause Button, and Rewind and Forward Buttons.}

The animation automatically paused at selected points (i.e., segments) in order to create five short sections. At each pause point, the viewer/student was prompted to either replay the previous section or to move on to the next 
section. The viewer/student also had the ability to, at any time, view any of the five sections in any order.

\section{Version 4 -Pace with Self-Explaining Environment.}

The animation paused between each of the five sections and students were prompted to self-explain what they were seeing and thinking. They did this in a textual format. After submitting their self-explanation, they moved to the next segment of the animation. Students were allowed to revisit each section of the animation in any order.

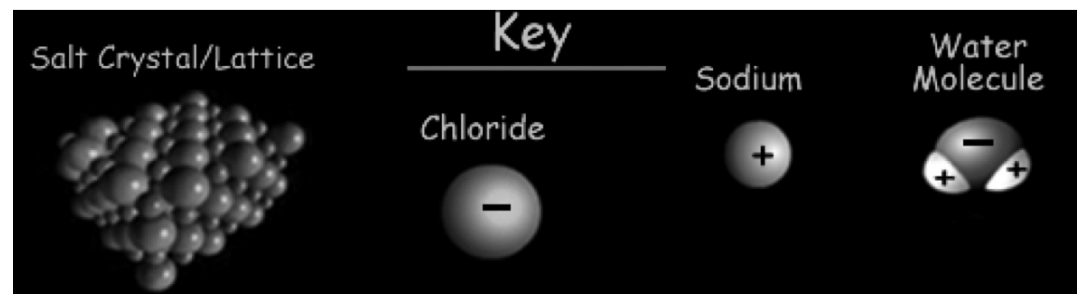

Figure 2: Table of key features in the animation.

Using SPSS, a general linear model multivariate ANCOVA was used to determine if any of the groups performed significantly better in the post-test. Using the Wilks' Lambda, the researchers explored three different aspects of the independent variables. The Wilks' Lambda (alpha $=.05)$ measures of the proportion of variance in the combination of dependent variables that is unaccounted for by the independent variable (the grouping variable). The analyses explored the effect of treatment, spatial ability and their interaction on transfer knowledge, understanding of structural components and understanding of functional components. Data regarding whether or not participants were science majors was used as a covariate in the analyses. The researchers used the Tukey test as a post-hoc analysis to maintain a family-wise alpha of .05.

This research also entailed a phenomenology with semi-structured interviews (Creswell, 1998). All five interviewees planned to become elementary school teachers and ranged in age from 18 to 25 . During the interviews, the researchers asked several questions to identify what participants found helpful and what they liked about the animation. Also, they were asked to consider their diagrammatic sketch from the previous study to establish a sense of what they understood, or to let them enhance their sketch by making it more understandable. 


\section{Results}

Using SPSS, the MANCOVA test (Table 1) produced significant results for the model on the structure and function retention dependent variables but not for the transfer variable. For the covariant (science or non-science majors), overall the science majors did better on structure $(p=.005)$ and function $(p=$ .o16) dependent variables (Table 2).

Table 1: MANCOVA tests of between-subjects effects.

\begin{tabular}{|c|c|c|c|c|c|c|}
\hline Source & $\begin{array}{l}\text { Dependent } \\
\text { Variable }\end{array}$ & $\begin{array}{r}\text { Type III Sum of } \\
\text { Squares }\end{array}$ & df & $\begin{array}{r}\text { Mean } \\
\text { Square }\end{array}$ & $\mathrm{F}$ & Sig. \\
\hline \multirow{3}{*}{ Corrected Model } & structure & $109.310^{\text {(a) }}$ & 8 & 13.664 & 4.496 & .000 \\
\hline & function & $18.095^{\text {(b) }}$ & 8 & 2.262 & 3.032 & .003 \\
\hline & transfer & $4.646^{(\mathrm{c})}$ & 8 & .581 & .840 & .569 \\
\hline \multirow{3}{*}{ Course (co-variable) } & structure & 24.456 & 1 & 24.456 & 8.048 & .005 \\
\hline & function & 4.383 & 1 & 4.383 & 5.875 & .016 \\
\hline & transfer & .793 & 1 & .793 & 1.147 & .286 \\
\hline \multirow{3}{*}{ Treatment } & structure & 7.007 & 3 & 2.336 & .769 & .513 \\
\hline & function & 11.674 & 3 & 3.891 & 5.217 & .002 \\
\hline & transfer & 1.321 & 3 & .440 & .637 & .592 \\
\hline \multirow{3}{*}{$\begin{array}{l}\text { Spatial ability } \\
\text { (high or low) }\end{array}$} & structure & 25.073 & 1 & 25.073 & 8.251 & .005 \\
\hline & function & .167 & 1 & .167 & .223 & .637 \\
\hline & transfer & .172 & 1 & .172 & .249 & .619 \\
\hline \multirow{3}{*}{$\begin{array}{l}\text { Treatment } \\
\text { Spatial ability }\end{array}$} & structure & 56.124 & 3 & 18.708 & 6.156 & .001 \\
\hline & function & .846 & 3 & .282 & .378 & .769 \\
\hline & transfer & 2.568 & 3 & .856 & 1.238 & .297 \\
\hline \multirow{3}{*}{ Error } & structure & 547.002 & 180 & 3.039 & & \\
\hline & function & 134.265 & 180 & .746 & & \\
\hline & transfer & 124.436 & 180 & .691 & & \\
\hline \multirow{3}{*}{ Total } & structure & 2651.000 & 189 & & & \\
\hline & function & 953.000 & 189 & & & \\
\hline & transfer & 762.500 & 189 & & & \\
\hline
\end{tabular}

Variance explained by model for each dependent variable:

\footnotetext{
(a) $\mathrm{R}^{2}=.167$ (Adjusted $\mathrm{R}^{2}=.130$ )

(b) $\mathrm{R}^{2}=.119$ (Adjusted $\mathrm{R}^{2}=.080$ )

${ }^{(c)} \mathrm{R}^{2}=.036\left(\right.$ Adjusted $\left.\mathrm{R}^{2}=-.007\right)$
} 
Table 2: Significant effects of the students' course of study, the co-variable, on the structure $(\mathrm{p}=.005)$ and function $(\mathrm{p}=.016)$ dependent variables.

Tukey HSD

\begin{tabular}{|l|r|r|r|}
\hline & & \multicolumn{2}{|c|}{ Dependent variables } \\
\cline { 3 - 4 } Course of study (co-variable) & $\mathrm{N}$ & $\begin{array}{c}\text { Structure } \\
\text { Mean }\end{array}$ & $\begin{array}{c}\text { Function } \\
\text { Mean. }\end{array}$ \\
\hline Science majors course & 115 & $3.543 \mathrm{~A}$ & $2.183 \mathrm{~A}$ \\
Non-science majors course & 74 & $2.790 \mathrm{~B}$ & 1.865 B \\
\hline Sig. Alpha = .05 Level & $p=$ & .005 & .016 \\
Means with the same letter (A or B) are not significantly different & & & \\
\hline
\end{tabular}

High-spatial students only scored higher than low-spatial students ( $\mathrm{p}=$ .005) in structural questions (Table 3 ). There was a significant interaction effect between treatment group and spatial ability $(\mathrm{p}=.001)$, as depicted in the graph in Figure 3.

Table 3: Significant effects of treatment groups on the function dependent variable $(p=.002)$.

Tukey HSD

\begin{tabular}{|l|r|r|r|}
\hline & & \multicolumn{2}{|c|}{ Function } \\
\cline { 3 - 4 } Treatment group & $\mathrm{N}$ & Mean & \multicolumn{1}{c|}{ Std Dev } \\
\hline 1: Control & 48 & $2.333 \mathrm{~A}$ & 0.808 \\
3: Pause and Pace & 48 & $2.271 \mathrm{~A}$ & 0.818 \\
4: Self-explain & 45 & $1.867 \mathbf{A B}$ & 1.014 \\
2: Pause & 48 & $1.750 \mathbf{~ B}$ & 0.838 \\
\hline Alpha = .05 & & & \\
Means with the same letter (A or B) are not significantly different & & & \\
\hline
\end{tabular}

Table 4: Significant effects of spatial ability on the structure dependent variable $(p=.005)$.

Tukey HSD

\begin{tabular}{|c|c|c|c|}
\hline \multirow[b]{2}{*}{ Spatial ability } & \multirow[b]{2}{*}{$\mathrm{N}$} & \multicolumn{2}{|c|}{ Structure } \\
\hline & & Mean & Std Dev \\
\hline High spatial ability & 78 & $3.653 \mathrm{~A}$ & 2.067 \\
\hline Low spatial ability & 111 & 2.964 B & 1.666 \\
\hline $\begin{array}{l}\text { Alpha }=.05 \\
\text { Means with the same letter (A or } \mathbf{B}) \text { are not significantly different }\end{array}$ & & & \\
\hline
\end{tabular}




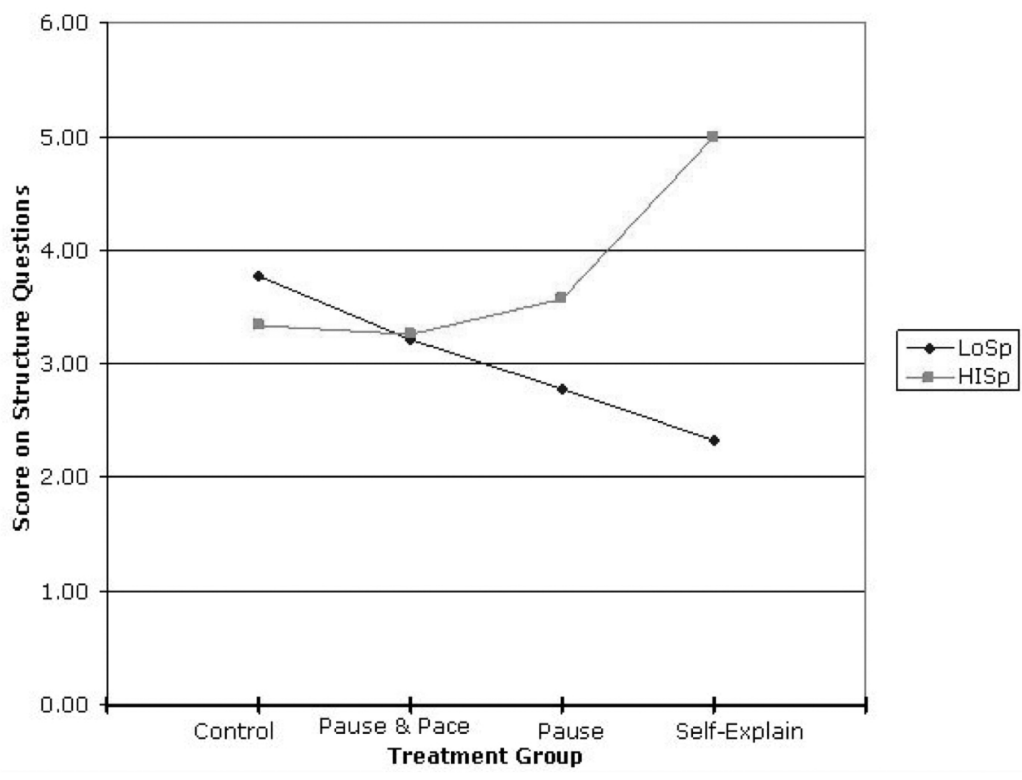

Figure 3: Significant interaction between treatment and spatial ability $(p=$ o.001) on the structure dependent variable.

The qualitative results in this study show that most participants believed the key and motion of ions and molecules were the most helpful parts of the animation. Students perceived the animations as being supportive of their learning and believed that animations have a role in the modern science classroom. When questioned about what they remembered about the animation they had viewed prior to seeing it again, three categories emerged relating to what students remembered about the animation: molecules, chemistry and other. Three themes emerged related to what students felt was helpful: a key, movement and audio. Of the five participants, three specifically mentioned the benefit of a key.

Many of the things that the participants liked about the animation overlapped with things they found to be helpful. For instance, in describing things they liked, two participants used the words "movement" and seeing the molecules "up close" (respectively). Another stated that the animation was "easier to understand than just somebody telling you what was going on" and "more entertaining." Adding more audio to the animation was the primary suggestion. According to Mautone and Mayer (2001), when narration emphasises key steps and associated links, students "learn more deeply" from a multimedia explanation (p. 387). One person indicated that the animation should also have audio 
on the first viewing, not just the last. Another person suggested using audio to define the charges, as in a verbal key (the animation narrator does this while the molecules are moving but it is not a separate entity, such as an introduction). One person wanted to see arrows pointing to the molecules identifying them within the animation.

At the end of each interview, participants were asked how they felt the animation would affect them as educators. One participant responded to this question with, "it's an interesting way to incorporate technology in the classroom...it's always nice for students to hear something from another point of view." Three others intimated the importance of visualisation to elementary students. Some literature would seem to agree. Tversky (2001) says that visualisations enhance cognitive competence. One of the participants said, “...kids are stimulated more by visuals... I think they'll be able to relate to this way of teaching more than writing stuff on a chalkboard or lecturing or seeing things in a book." This statement is also significant because she had only heard the narration, and had not actually seen the animation. She stated, “...I think it's a good thing. I think it gives a visual and that helps a lot of people learn, to see an actual visual that is a representation, instead of just hearing it."

\section{Discussion}

Science majors outscored non-science majors in both retention measures, i.e., structure and function questions in the post-test (Table 2). The science majors had been briefly exposed to salts dissolving in water previously; however, their prior knowledge was limited to mostly symbolic representations in lectures and mostly hands-on experiences with the dissolving process in the laboratory portion of their course. Conversely, the non-science majors had little or no prior knowledge of this process. This lack of prior knowledge was probably responsible for the latter group's inability to organise the verbal and visual information from the animation into coherent mental models (Cook, 2006; Schnotz, 2002). These students focused on salient surface features, such as the colour of the spheres used to represent ions and molecules (i.e., structural features) rather than the relative positions of the structures, which gives meaning to chemists as domain experts. Apparently, the three treatment versions designed to reduce extrinsic cognitive load for the non-science majors could not overcome the intrinsic load imposed by the interrelated set of ionic and molecular structures and their associated functions (Chandler \& Sweller, 1991). The lack of significant difference between science and non-science majors on transfer measures suggests that the former were also not able to form coherent mental models. Perhaps the science majors' 
unfamiliarity with the medium (they were not accustomed to viewing molecular animations) was a factor in preventing them from developing a conceptual understanding of the dissolving process.

Treatment produced a significant difference in the function-dependent variable (Table 3 ). The fact that none of the three treatments designed to reduce extrinsic load outperformed the control group in function questions suggests that the extrinsic load for students in these treatments remained relatively high. Hence, they were unable to free the cognitive capacity needed to process intrinsic loads of the functions involved in the dissolving process. The control and pauseand-pace groups both outperformed the pause group, which suggests that the latter may have experienced an extra extrinsic load when students had to decide when to "pause" as they were viewing a molecular process that had too many unfamiliar stimuli.

Another explanation for these results is that the control version went rather quickly, so students may have replayed the animation several times in order to understand it. The pause button version slowed the animation somewhat, so students may not have replayed it multiple times. For this group, the animations likely caused extrinsic cognitive load because students had to think about and decide when and where to pause the animation. Confirming Mayer's (2003) findings, pace (breaking the animation into five segments) helped students with function questions. Students wondering why something happened in the animation were able to go back and view the segment of the animation again to help them understand. The control group did just as well because students viewed the animation multiple times. However, because students did not have a basic cognitive mental model for the function components, they were not able to capitalise on self-explaining the concepts. It is likely that students in the self-explaining treatment group did not repeat the segments of the animation. Repeated viewing of the animation, or sections of it, may have helped students better understand functional components of the concept. This is an area worthy of further research.

The study found a spatial ability effect where high spatial ability students outperformed their low-ability counterparts in structure questions only (Table 4). As shown in Figure 3, the self-explanation treatment greatly enhanced the performance of high spatial ability students while it inhibited the learning of low spatial ability students. These results are in contrast to those found with the control group, which produced essentially no differences between high-spatial and low-spatial groups. This implies that the self-explanation treatment reduced the extrinsic cognitive load of high-spatial learners such that they were able to free cognitive capacity to provide a greater intrinsic load, which allowed development of a coherent mental model for the structures shown in the animation. 
Thus, high-spatial learners gained from the simultaneous presentation of visual representations in the animation and verbal representations in the narration apparently because they had time to reflect upon their nascent mental model during the pause after each of the five segments. However, segmentation into meaningful stages was insufficient to allow the formation of mental models because students viewing Version 3 (pause-and-pace, which also had segmentation) did not outperform the control group. As predicted by self-explanation literature (Chi, 1996, 2000; Sweller, van Merrienboer, \& Paas, 1998), the self-explanation group was prompted several times during the animation to explain the segment they had just viewed. This prompting allowed them to develop a deeper understanding of the domain (i.e., the dynamic molecular process) by forming a meaningful mental model for each segment. Since experts had decided where to place these pauses between meaningful segments, the high-spatial learners were apparently making the link between their perceptual representations and their conceptual representations of the dissolving process.

In sharp contrast to the above, the low-spatial learners did not benefit from the pause or self-explain treatments apparently because they could not simultaneously process the verbal/narration and visual/animation information given in each segment. When asked to explain what they had just viewed, they may have experienced an extra extrinsic cognitive load in which their knowledge was incomplete and their self-confidence may have been eroded. Meanwhile, low-spatial learners in the control group, who outperformed their counterparts in the self-explain group, may have replayed the entire animation several times in order to try to integrate verbal and visual information. The discontinuous animation experienced by low-spatial learners in the other two treatment groups must have also adversely affected their understanding of the molecular process; that is, the pause button (see Figure 4) for low-spatial learners in these treatment groups may have induced an extrinsic cognitive load relative to the low-spatial learners in the control group, who experienced the continuous-play animation.

In terms of the qualitative data, the primary finding of this study is that students felt the key was a critical component of the animation. Many liked the fact that there was movement in the animation, such as "zooming in on" and seeing "up close" through multiple visual angles. Colour and audio narration were also described as things the participants liked. Few dislikes were described. The comments included seeing the key before viewing the animation, and having labels that pointed to objects being described in the animation. Most of the students interviewed indicated that they would have liked more audio narration; for example, during the first run through the animation and during the presentation of the key. Several participants stated that they did not foresee ever 
being in a situation where they would use this type of animation in elementary education.

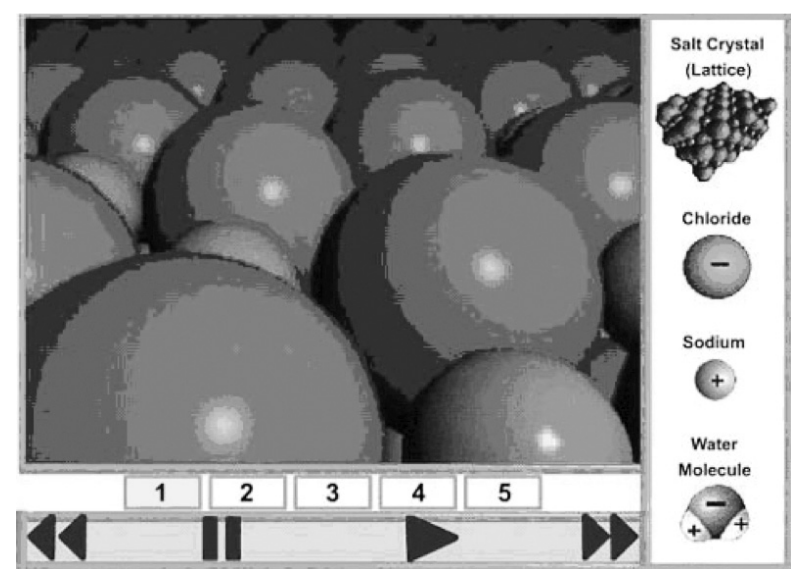

Figure 4: Screen shot of the interface design of the animation including controls.

\section{Conclusions}

High-spatial learners need to pause after each meaningful segment and self-explain what they have just experienced in terms of visual and verbal information so they can develop effective mental models (Chi et al., 1982). Conversely, low-spatial learners may need animations that they can "play" continuously until they get an intuitive feel for the process being represented. Perhaps after several replays, they could try to explain to another student what they appear to understand in a more "holistic and flowing" manner rather than in a playby-play manner filled with explicit details that could overload cognitive capacity. However, these results have to be interpreted cautiously because the effects were certainly not widespread over both retention and transfer measures. More research is needed to determine how to best structure and use these innovative tools. If animations are to live up to their promise to improve teaching and learning in science, researchers must continue to address how to best integrate these tools into science classrooms.

\section{Acknowledgements}

The authors would like to thank Dr. Loretta Jones, Principal Investigator, National Science Foundation Award (REC-0440103), and her research 
associates for their support of this research. Additionally, several collaborators and graduate students, including Ben Johnson and Patty Cantrell, made essential contributions to this study. Lastly, the authors would like to thank Dr. Richard Mayer and Dr. Mary Hegarty for their advice regarding this research.

\section{References}

Atkinson R. K., Renkl, A., \& Merrill, M. M. (2003). Transitioning from studying examples to solving problems: Effects of self-explanation prompts and fading worked-out steps. Journal of Educational Psychology, 95(4), 774-783.

Chandler, P., \& Sweller, J. (1991). Cognitive load theory and the format of instruction. Cognition and Instruction, 8(4), 293-332.

Chi, M. (1996). Constructing self-explanations and scaffolded explanations in tutoring. Applied Cognitive Psychology, 10(7), 33-49.

Chi, M. (2000). Self-explaining: The dual processes of generating inferences and repairing mental models. In R. Glaser (Ed.), Advances in Instructional Psychology (pp. 161-238). Mahwah, NJ: Lawrence Erlbaum Associates.

Chi, M., DeLeeuw, N., Chiu, M. H., \& Lavancher, C. (1994). Eliciting self-explanations improves understanding. Cognitive Science, 18, 439-477.

Chi, M., Glaser, R., \& Rees, E. (1982). Expertise in problem solving. In R. Sternberg (Ed.), Advances in the psychology of human intelligence (pp. 7-75). Hillsdale, NJ: Erlbaum.

Cook, M. P. (2006). Visual representations in science education: The influence of prior knowledge and cognitive load theory on instructional design principles. Science Education, 9o(6), 1073-1091. Creswell, J. W. (1998). Qualitative inquiry and research design: Choosing among five traditions.

Thousand Oaks, CA: Sage.

Gabel, D. L. (2005). Handbook on Science Teaching and Learning: A Project of the National Science

Teacher Association. New York: Macmillan.

Johnstone, A. H. (1993). The development of chemistry teaching: A changing response to changing demand. Journal of Chemical Education, 7o(9), 701-704.

Kelly, R. M. (2005). Exploring how animations of sodium chloride dissolution affect students' explanations. Unpublished doctoral dissertation, University of Northern Colorado.

Linn, M. (2003). Technology and science education: Starting points, research programs, and rends. International Journal of Science Education, 25(6), 727-758.

Martin, B. \& Tversky, B. (2003). Segmenting ambiguous events. In Proceedings of the Cognitive Science Society Meetings, (pp. 234-238). Boston.

Mautone, P. D., \& Mayer, R. E. (2001). Signaling as a cognitive guide in multimedia learning. Journal of Educational Psychology, 93(2), 377-389.

Mayer, R. E. (2001). Multi-media learning. Cambridge, UK: Cambridge University Press.

Mayer, R. (2003). The promise of multimedia learning: Using the same instructional design methods 
across different media. Retrieved 05.01.2005 from http://www.unisanet.unisa.edu.au/edpsych/ external/EDUC_5080/Mayer.pdf.

Mayer, R. E., \& Moreno, R. (2003). Nine ways to reduce cognitive load in multimedia learning. Educational Psychologist, 38(1), 43-52.

Nakhleh, M. (1993). Are our students conceptual thinkers or algorithmic problem solvers? Journal of Chemical Education, $70(1), 52-55$.

Nurrenbern, S. C., \& Pickering, M. (1987). Concept learning versus problem solving: Is there a difference? Journal of Chemical Education, 64(6), 508-509.

Peters, M., Laeng, B., Lathan, K., Jackson, M., Zaiouna, R., \& Richardson, C. (1995). A redrawn Vandenberg and Kuse mental rotations test: different versions and factors that affect performance.

Brain and Cognition. 28(1), 39-58.

Sawrey, B. (1990). Concept learning versus problem solving: Revisited. Journal of Chemical Education, 67(3), 253-254.

Schar, S. G., \& Zimmermann, P. G. (2007). Investigating means to reduce cognitive load from animations: Applying differentiated measures of knowledge representation. Journal of Research on Technology in Education, 4o(1), 64-78.

Schnotz, W. (2002). Towards an integrated view of learning from text and visual displays. Educational Psychology Review, 14(1), 101-120.

Sweller, J., van Merrienboer, J. J. G., \& Paas, F. G. (1998). Cognitive architecture and instructional design. Educational Psychology Review, 10(3), 251-296.

Tasker R., (2004). Using multimedia to visualize the molecular world: educational theory into practice. In T. Greenbowe, \& M. Cooper (Eds.), A Chemist's Guide to Effective Teaching (pp. 256-272). New York: Prentice Hall.

Tasker, R., Dalton, R., Sleet, R., Bucat, B., Chia, W. \& Corrigan, D. (2002). Description of VisChem: Visualising chemical structures and reactions at the molecular level to develop a deep understanding of chemistry concepts. Retrieved 20.01.2007 from Learning Designs Web site: http://www. learningdesigns.uow.edu.au/exemplars/info/LD9/index.html.

Tversky, B. (2001). Spatial schemas in depictions. In M. Gattis (Ed.), Spatial schemas and abstract thought (pp. 79-111). Cambridge: MIT Press.

Tversky, B. (2005). Visuospatial Reasoning. In K. J. Holyoak, \& R. G. Morrison (Eds), The Cambridge Handbook of Thinking and Reasoning (pp. 209-242). New York: Cambridge University Press.

Vandenberg, S. G., \& Kuse, A. R. (1978). Mental rotations: A group test of three-dimensional spatial visualization. Perceptual and Motor Skills, 47(2), 599-604.

Zacks, J. M., \& Tversky, B. (2003). Structuring information interfaces for procedural learning. Journal of Experimental Psychology, Applied. 9(2), 88-100. 


\section{Biographical note}

David A. Falvo, Dr., is a full-time Core Faculty Member in the Richard W. Riley College of Education and Leadership at Walden University. Dr. Falvo served as key personnel on an NSF grant studying the use of animations for teaching chemistry, and on numerous research projects about educational technologies. His research interests include online learning systems (designs and tools), interface usability, collaborative learning, and teacher professional development.

Michael J. Urban, Dr., teaches instructional technology, science teaching methods, and other education courses. He is a faculty member at Bemidji StateUniversity. He has taught science and technology in PK-12 Schools, community colleges, and Universities. His research interest includes integration of technology for science and mathematics learning, instructional design, and inquiry learning environments.

Jerry P. SuIts, Dr., is an Associate Professor in the Department of Chemistry and Biochemistry at the University of Northern Colorado. His research focuses on the factors affect how students learn chemistry. He has found that most students tend to be memorizers (a learning style) until they have acquired a certain amount of chemical knowledge (a critical mass) that allows them to become conceptualizers (i.e., they are able to form concepts out of facts and rules). 